\title{
AN EIGHTEENTH-GENTURY NAVAL SHIP TO ACCOMMODATE WOMEN NURSES
}

by

\author{
The late CHARLES SINGER*
}

FROM the seventeenth century onward-and indeed long before-the help of women as nurses for the sick and wounded was occasionally invoked on board battleships. However, by the seventeenth century-and even more in the early years of the following century-the establishment, now known as the Admiralty, had begun to assume some of the characteristics known to us today. Accommodation for the sick and wounded were beginning to be elaborated. Thus in Volume II of the late Surgeon Commander Keevil's admirable Medicine and the Navy (1958) we read:

To the suggestion that some of the ship's company were 'lodged among the sick men', the Board replied with an unqualified denial, but the order presently to be made casts doubt on this: it directed that 'no ship be hired unless the gun deck can be reserved entirely for accommodation of the sick'. Further orders called for extra scuttles for ventilation, the removal of bulkheads 'to make all flush', and the isolation of infectious cases by means of canvas screens. The new orders prohibited the employment of women on board, although under William III each hospital ship had been allowed six nurses and four laundresses, 'none under the age of fifty years. Query whether they should not all be seamen's wives or widows', who were to be paid as ordinary seamen; these changes were all effected after they had been recommended in 1703 by Sir George Byng and the Surveyor of the Navy, but the prohibition regarding women was found to be so inconvenient and unreasonable that it was cancelled shortly afterwards. A hospital ship in the Mediterranean in 1705 carried five nurses and three laundresses.

That there was some need for this additional help is evident from the Commissioners' suggestion that the watch over the sick was inadequate. But to this the Board replied 'that the assistants [surgeons?] watch by turns four and four at a time'. This is the first clear case of ratings being carried for no other than medical duties. The payment of these assistants as ordinary seamen corresponds to the present practice regarding sick-berth attendants. These eighteenth-century male nurses appear to have had their own mess, for the Board admitted that they did their watchkeeping from their 'lodgings' on the gun-deck, from which they could easily be called.

I do not know the history of the medical ratings in the eighteenth century. This will doubtless be told in the continuation of Keevil's book which is in hand. But it is a fact that during that century large warships carried, presumably apart from the surgeons' mates and beyond sailors and marines, a few male nursing-orderlies. These wore a special dress. They are familiar from some of the many pictures of Nelson's death at the Battle of Trafalgar in 1815 .

* This article was sent to Medical History by Dr. Singer shortly before his death and represents one of the last pieces of literary work completed by him. A second contribution which he was writing for Medical History -an important review of Vesalian studies during the last eighteen years-is now being edited for publication in this journal at an early date. A memoir of Dr. Singer, together with a list of his later writings, will be found on page 353 of this issue of Medical History. 


\section{Charles Singer}

It seems unlikely that women nurses were used in ships that engaged in conflict.

The first case known to me of a ship specially prepared for women nurses dates from 1795 . The task of this ship is described by Dr. James Carmichael Smyth (I74I-182I) in a pamphlet bearing the long title 'An Account of the Experiment made at the desire of the Lords Commissioners of the Admiralty, on board the Union Hospital Ship to determine the effect of the Nitrous Acid in destroying Contagion, and the safety with which it may be employed. In a letter addressed to The Right Hon. Earl Spencer.' This was issued in 1796 by the well-known printer and publisher John Johnson in St. Paul's Churchyard. It is prefaced by plans of the three cabin-decks of H.M.S. Union (Fig. I). These show that there was a matron and at least fifteen nurses on board, for there were fifteen cabins for nurses though there is no indication as to whether each cabin for nurses contained one or more berths. A lieutenant was in command of the ship which carried also a surgeon and six surgeons' mates or dressers and a purser. There were moreover at least two cabins for 'washerwomen'. There was a crew of a bosun, a carpenter, and a number of seamen and marines. The sanitation of H.M.S. Union had been so rearranged that it projected from the side of the vessel instead of being within it.

H.M.S. Union saw service under special conditions. At that time there were many British naval ships at Sheerness and presumably the sick from them would normally be brought aboard the Union. But a Russian fleet put in infected with typhus and there was a very heavy death rate in the crews. All the Russian sufferers that could be accommodated were brought on board the Union and looked after by the nursing staff. Dr. Smyth was at once sent for from London. He was himself an authority on this deadly disease, then usually known as 'jail distemper'.

Dr. Smyth had already extensive experience of typhus for he had been in charge of an outbreak of it among Spanish prisoners at Winchester in 1780. He there secured, or claimed to have secured, a notably low death rate by methods presently described. He himself suffered from the disease in a mild form. During the attack he hardly kept his bed, seeing patients almost daily. He must have been a very brave and determined man but by I 795, at the time of the outbreak at Sheerness, he was of course immune.

Nothing was then known of the special relation of typhus to lice. Nevertheless Smyth's method of treatment was rational enough. He laid the greatest stress on cleanliness, thorough bathing and disinfection of clothes and bedding, and shaving of heads and beards. No patient who, it was thought, might develop the disease was put in other than newly washed bedding. Smyth regarded this process as what he called 'antiseptic', a word which he not infrequently used. The word, in fact, long anticipated him. He found that the Russians wore sheepskin tunics with the hair turned inward and he regarded these as a special source of infection, which of course they were.

In addition to cleanliness and repeated washing, both of person and of clothes of all concerned, he recommends fully airing every cabin or enclosed 


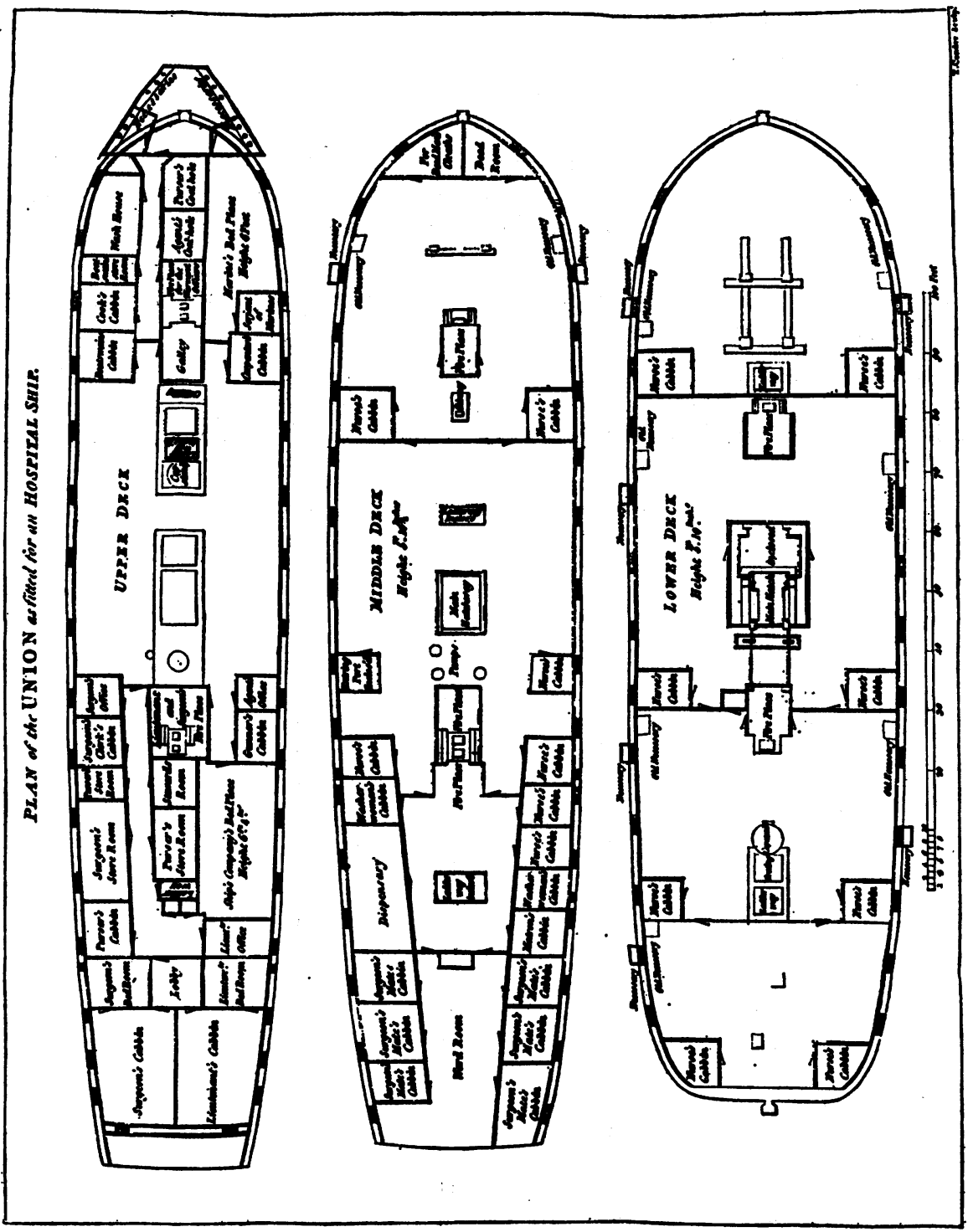




\section{Charles Singer}

space twice daily, and on each occasion its disinfection with what he records as an 'antiseptic gas' derived from heating crude nitre presumably with carbon. This must have given off oxides of nitrogen which would have been fatal to lice. He was against bleeding, then much used, and his drug treatment was mild and at least did no harm.

During the epidemic, no less than eleven nurses became infected and three died. Three washerwomen were also infected and two of them died. The work of the washerwomen naturally brought them into very close contact with infected clothes and bedding. The proportion of deaths in the staff cannot be estimated since we do not know to what extent it was changed but Dr. Smyth does tell us that there were also a number of cases among the male staff. The first mate, two marines and a seaman died of typhus.

The mortality among the Russian patients on the Union may be gathered from the following report of the surgeon.

A Weekly Return of the Russians received on Board his Majesty's Hospital Ship Union, in the Malignant Fever from the 3rd of September 1795, to the 28th of January 1796, exclusive of those received in a state of debility after the said Fever, and with other diseases. By A. Bassan, Surgeon of His Majesty's Ship Union.

\begin{tabular}{|c|c|c|c|c|}
\hline \multicolumn{2}{|c|}{ Sept. I795 } & Received & Discharged & Dead \\
\hline Sept. & 3 & 37 & & \\
\hline$"$ & 10 & 37 & $\mathbf{I}$ & \\
\hline " & 17 & 4 & 7 & \\
\hline " & 24 & 34 & 7 & I \\
\hline Oct. & I & 17 & 17 & 5 \\
\hline , & 8 & 29 & 15 & \\
\hline$"$ & I5 & 20 & 5 & 2 \\
\hline " & 22 & 15 & 14 & I \\
\hline & 29 & 18 & II & I \\
\hline Nov. & 5 & 31 & 9 & I \\
\hline " & 12 & 21 & I3 & \\
\hline " & 19 & 20 & 44 & 5 \\
\hline & 26 & 29 & 39 & I \\
\hline Dec. & 3 & 12 & 5 & I \\
\hline " & 10 & 12 & 16 & I \\
\hline " & 17 & 35 & 48 & \\
\hline " & 24 & 8 & 25 & I \\
\hline " & 31 & 40 & I & \\
\hline 1796 & & & & \\
\hline Jan. & 7 & 32 & 25 & 3 \\
\hline ", & 14 & 13 & 7 & 2 \\
\hline " & 21 & 20 & 24 & 3 \\
\hline " & 28 & 22 & 23 & 6 \\
\hline & Total & 479 & 356 & 34 \\
\hline
\end{tabular}

The greater part of the Russian squadron sailed on a cruise November 29, and returned into port December 27, two or three ships at a time.

From the above return it appears, that the number of persons ill of the contagious fever, brought on board the Union, the two last months, December 1795 and January 1796, were 


\section{An Eighteenth-Century Naval Ship to Accommodate Women Nurses}

nearly equal to the number received the two preceding months, October and November. It also appears that for the first month, after the ship was fumigated, there were few fever patients who died. The increase in the number of deaths in the following month, may fairly be ascribed to the return of the fleet.

To all this the ship-surgeon, Mr. Bassan, adds the following note to Dr. Carmichael Smyth, under date, 6 February 1796.

Dear Sir,

We had an encreased mortality amongst the Russians last month, but, thank God, not from the contagious fever, that being now total extinct; but some being brought in a dying state, others in the scurvy, the most deplorable cases I ever saw, added to which, several hectic patients, who had been declining some time, happened to die at that particular period. I hope we shall have no return of so dreadful a calamity.

I remain,

Sir,

Your most obedient Servant, etc.,

A. BASSAN

The hospital ship was about 160 feet long and about 45 feet wide. Perhaps some readers can tell of earlier cases of female nurses being regularly employed on board ship. I think that they must have been regularly used in naval ships at a much earlier date because neither Smyth nor Bassan refer to their presence as anything unusual. So far as the account goes, the ship did not put to sea though it was equipped to do so.

To give a clearer idea of the character and fatality of an epidemic in those days we add Dr. Smyth's table of sickness in the outbreak of typhus among Spanish prisoners which he had tackled fifteen years earlier.

Office for sick and wounded Seamen, etc.

A Weekly progressive State of the Sickness and Mortality among the Spanish Prisoners, confined in the King's House, at Winchester, from the first Appearance of the Jail Distemper, until the 8th of July 1780 .

\begin{tabular}{|c|c|c|c|c|c|}
\hline \multirow{2}{*}{\multicolumn{3}{|c|}{$\begin{array}{c}\text { Date of } \\
\text { Weekly Accounts }\end{array}$}} & \multicolumn{3}{|c|}{ Number of Spanish Prisoners } \\
\hline & & & In Custody & Sick & Dead \\
\hline March & 26 & 1780 & 1247 & 60 & $\mathbf{I}$ \\
\hline April & 2 & و & 1243 & 106 & 4 \\
\hline " & 9 & " & 1475 & 150 & 10 \\
\hline " & 16 & $"$ & 1457 & 172 & 18 \\
\hline " & 23 & " & 1433 & 142 & 21 \\
\hline „, & 30 & " & 1412 & 171 & 21 \\
\hline May & 7 & $"$ & 1388 & 191 & 25 \\
\hline " & 14 & " & 1351 & 197 & 27 \\
\hline " & 21 & " & 1523 & 205 & 30 \\
\hline 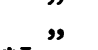 & 28 & 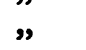 & 1494 & 226 & 31 \\
\hline *June & 3 & ", & 1461 & 262 & 33 \\
\hline , & 10 & " & 1437 & 212 & 26 \\
\hline " & 17 & " & 1426 & 173 & 9 \\
\hline 3 & 24 & " & 1420 & 167 & 5 \\
\hline July & I & " & 1414 & 143 & 5 \\
\hline " & 8 & " & 1433 & 122 & 2 \\
\hline
\end{tabular}

* The time of Dr. Carmichael Smyth's going to Winchester. 